\title{
Simultaneous Detection and Survey of Three Rice Viruses in China
}

Wei-Qi Wu and Xi-Gui Guo, College of Chemistry and Life Science, Zhejiang Normal University, Jinhua 321004, China, State Key Laboratory Breeding Base for Zhejiang Sustainable Pest and Disease Control, Key Laboratory of Plant Protection and Biotechnology, Ministry of Agriculture, China, and Zhejiang Provincial Key Laboratory of Plant Virology, Institute of Virology and Biotechnology, Zhejiang Academy of Agricultural Sciences, Hangzhou 310021, China; and Heng-Mu Zhang, Jian Yang, Ming-Fang Lv, and JianPing Chen, State Key Laboratory Breeding Base for Zhejiang Sustainable Pest and Disease Control, Key Laboratory of Plant Protection and Biotechnology, Ministry of Agriculture, and Zhejiang Provincial Key Laboratory of Plant Virology, Institute of Virology and Biotechnology, Zhejiang Academy of Agricultural Sciences

\begin{abstract}
Wu, W.-Q., Guo, X.-G., Zhang, H.-M., Yang, J., Lv, M.-F., and Chen, J.-P. 2013. Simultaneous detection and survey of three rice viruses in China. Plant Dis. 97:1181-1186.

Rice black-streaked dwarf virus, Rice stripe virus, and Southern rice black-streaked dwarf virus (SRBSDV) have been epidemic in large areas of China where rice is grown, causing significant losses of rice yield in recent years. These viral diseases sometimes occur in the same regions, and even in the same fields, making it difficult to detect and diagnose the viral pathogens. A set of primers specific to the genes encoding the capsid proteins of the three viruses were designed, and a multiple one-step reverse-transcription polymerase chain reaction protocol was developed. The method proved to be simple, rapid, and sen-

sitive. It was used to detect the viruses in samples of rice, maize, small brown planthoppers, and white-backed planthoppers collected from different regions of China, showing that it is suitable for routine diagnosis. A simultaneous survey of the three viruses was further conducted by this method throughout Zhejiang Province, Eastern China. The results showed that both RBSDV and RSV had continued to spread and that the newly emerging virus, SRBSDV, was present in at least 27 counties or cities, suggesting that more effort is needed to monitor and control the threat from these three viral diseases.
\end{abstract}

In recent years, Rice black-streaked dwarf virus (RBSDV; genus Fijivirus, family Reoviridae) and Rice stripe virus (RSV; genus Tenuivirus), that were first reported from China in the Yangtze River Delta in the early 1960s, have reemerged and have rapidly become prevalent in some rice-growing areas of China $(10,14)$. Rice stripe disease has expanded rapidly since 1999 and had spread to $1,530,000$ ha by July 2004 in more than 40 counties of Jiangsu Province (11). RSV-infected rice plants often display chlorotic stripes, chlorosis, moderate stunting, and loss of vigor. RBSDVinduced symptoms on rice plants typically include pronounced stunting, darkening of leaves, and white waxy or black-streaked swellings along the veins on the underside of the leaf blades, sheaths, and culms. Diseased rice plants with RSV or RBSDV often produce poor heads or none at all, leading to significant loss of yield.

Southern rice black-streaked dwarf virus (SRBSDV) is a novel member of the second group of fijiviruses $(15,17)$ that induces symptoms similar to those of RBSDV on rice and maize plants (Supplementary Figure 1). It was first reported in 2001 in Yangjiang City, Guangdong Province, China, and was initially considered an isolate of RBSDV because of its particle morphology and serological similarity to RBSDV (18) but is now considered distinct on the basis of sequence analysis and differences in vector specificity (see below). Since 2009, the disease caused by SRBSDV has become one of the most important viral diseases in China. By 2010, it had been reported on more than $6,000,000$ ha of

Corresponding authors: H.-M. Zhang, E-mail: zhhengmu@tsinghua.org.cn; and J.-P. Chen, E-mail: jpchen2001@yahoo.com.cn

W.-Q. Wu and X.-G. Guo contributed equally to this work.

* The $\boldsymbol{e}$-Xtra logo stands for "electronic extra" and indicates that a supplementary figure is available online.

Accepted for publication 23 February 2013.

http://dx.doi.org/10.1094/PDIS-02-12-0207-RE

(C) 2013 The American Phytopathological Society rice in 14 provinces of southern, eastern, and central China and in more than 29 provinces of northern and central Vietnam $(8,12,19)$. All three viruses can be transmitted by planthoppers in a persistent manner and naturally infect rice, maize, sorghum, barnyard grass, and other graminaceous crops and weeds. RBSDV and RSV are transmitted by the small brown planthopper (SBPH), Laodelphax striatellus Fallen. SRBSDV appears to be only poorly transmitted by SBPH but efficiently transmitted by the white-backed planthopper (WBPH), Sogatella furcifera Horvath, which is a widespread migratory pest throughout the main rice-growing areas in China (7). Because of their host range and epidemiological properties, the three viral diseases often overlap to some degree in some regions, particularly in Eastern China. During 2009 to 2011, studies in Zhejiang Province showed that all three viruses and both plant hoppers (SBPH and WBPH) occurred in the same county and even in the same paddy fields and same rice plants. The similarity of symptoms and complex patterns of infection in fields make diagnosis difficult but accurate measurement of the proportion of viruliferous planthoppers is pivotal for predicting and monitoring epidemics and for control of these viral diseases. Enzyme-linked immunosorbent assay is a useful method for high-throughput detection of viruses due to its low cost; however, there is a close serological relationship between RBSDV and SRBSDV and an antiserum that can discriminate between the two has not yet been prepared. Therefore, with their genomic sequences determined, molecular methods were established for detection of these viruses. A nested or one-step reverse-transcription polymerase chain reaction (RT-PCR) was developed for distinguishing SRBSDV from $\operatorname{RBSDV}(3,17,20)$. A recent report describes a reverse-transcription loop-mediated isothermal amplification assay for detection of nine rice viruses (5) but this assay does not include SRBSDV. Here, we describe an alternative simple, rapid, and sensitive method for simultaneous detection of the three major rice viruses that occur at present in Eastern China and its use to detect these viruses in single planthoppers and in naturally infected rice plants.

\section{Materials and Methods}

Plant, insect, and virus samples. Purified samples of RSV, RBSDV, and SRBSDV, identified as described previously 
$(13,15,16)$, were stored at $-80^{\circ} \mathrm{C}$. Symptomatic rice and maize plants were collected from Zhejiang, Shandong, Hubei, Hunan, Hainan, Guangdong, and Shanghai Provinces, China and from several provinces in northern Vietnam and stored at $-80^{\circ} \mathrm{C}$. Planthoppers (SBPH and WBPH) were collected from Zhejiang, Hainan, Hunan, Shanghai, and Shandong Provinces in China and stored in $70 \%$ ethanol.

Total RNA extraction. TRIzol Reagent (Invitrogen) was used for both plant and insect RNA extraction. For plant samples, leaf tissue (about $100 \mathrm{mg}$ ) of each plant sample was ground to a fine powder in liquid nitrogen, transferred to a sterile 1.5-ml Eppendorf tube ,and then mixed with $1 \mathrm{ml}$ of TRIzol Reagent. For insect samples, a single planthopper was homogenized in a sterile $1.5-\mathrm{ml}$ Eppendorf tube with a glass stick in $300 \mu \mathrm{l}$ of TRIzol Reagent. Samples were then processed according to the manufacturer's instructions. The resultant total RNAs were stored at $-80^{\circ} \mathrm{C}$.

Primer design. Sequences of RSV, RBSDV, and SRBSDV genes from GenBank database and some determined (but unpublished) from our laboratory were aligned with Clustal W 2.0 (4) to find suitable regions; then, intraspecific primers for the three rice viruses were designed using Primer Premier 6.0. (http://www. PremierBiosoft.com; Premier Biosoft International).

One-step RT-PCR or multiple RT-PCR. RT-PCRs were carried out using the One-step RT-PCR Kit (Takara) in a $25-\mu l$ reaction mixture, including $2.5 \mu \mathrm{l}$ of total RNA (50 ng to $1 \mu \mathrm{g}$ ) extracted from plant and insect samples templates, and other components added according to the manufacturer's instructions. The RT-PCR reactions used the following program: a reverse transcription at $50^{\circ} \mathrm{C}$ for $30 \mathrm{~min}$; a predenaturation step at $94^{\circ} \mathrm{C}$ for 2 min; 30 cycles of $30 \mathrm{~s}$ at $94^{\circ} \mathrm{C}, 30 \mathrm{~s}$ at 60 to $72^{\circ} \mathrm{C}$, and 30 to $60 \mathrm{~s}$ at $72^{\circ} \mathrm{C}$; and a final extension at $72^{\circ} \mathrm{C}$ for $10 \mathrm{~min}$. For reliable detection, every sample was analyzed with RT-PCR in triplicate.

Electrophoresis and sequencing of RT-PCR products. The products amplified by RT-PCR were electrophoresed on a 1.2-to$1.5 \%$ agarose gel and visualized under UV light after staining with ethidium bromide. Electrophoresis images were acquired using the UVP Biospectrum AC imaging system (UVP LLC) and the relative quantification of bands was analyzed using UVP VisionWorks LS Software (version 6.4.3; UVP LLC). Some fragments were excised from agarose gel, purified with the QIAquick Gel Purification Kit (Qiagen), and used for sequencing with the BigDye Terminator Cycle Sequencing Ready Reaction Kit (Perkin Elmer) on an ABI PRISM 377 DNA Sequencer according to the manufacturer's instructions.

\section{Results}

Primer design and optimum annealing temperature. Previous studies have shown that the genes encoding the capsid protein are among the most conserved and are also expressed at the highest levels in infected plant hosts and insect vectors $(2,6,13-15)$. Therefore, we targeted the genes encoding the nucleocapsid protein of RSV and the major outer capsid proteins of RBSDV and SRBSDV. For design of our specific primers, it was important to find the regions that were highly conserved within each species but which differed between the species. Therefore, we aligned all of the known (published and unpublished) nucleotide sequences of the capsid protein genes from RSV, RBSDV, and SRBSDV and then designed three pairs of primers (Table 1) in which DRS-1/2, DRB$1 / 2$, and DRZ-1/2 were specific for detection of RSV, RBSDV, and SRBSDV, respectively. To eliminate false negatives, we selected the Actin gene as an internal reference. To design a pair of universal degenerate primers for amplification of actin genes from SBPH, WBPH, maize, and rice plants, we cloned the full-length coding region of Actin genes from SBPH and WBPH (unpublished) and aligned them with those of rice and maize plants obtained from GenBank. To optimize the conditions of the amplification reaction, we first chose infected rice plants, which had been identified and described previously $(13,15,16)$, as standard samples for preliminary experiments. To explore a suitable annealing temperature for these primers, we performed four groups of gradient RT-PCRs with these primers from the standard samples of the three viruses. The results indicated that all the virus-specific target fragments were efficiently amplified at the annealing temperature of 59.8 to $66.5^{\circ} \mathrm{C}$ (Fig. 1). For our standard test, we used an annealing temperature of $63^{\circ} \mathrm{C}$, which was closest to the optimum and equally efficient for all three viruses and Actin genes.

Analysis of specificity and sensitivity. To analyze the specificity of the RT-PCR, we performed separate one-step RT-PCRs with the four pairs of primers using each of the standard samples. The primer pairs amplified fragments from the virus against which they were designed but from no other samples. Specificity was retained when the primers were mixed in equal quantities and used with the

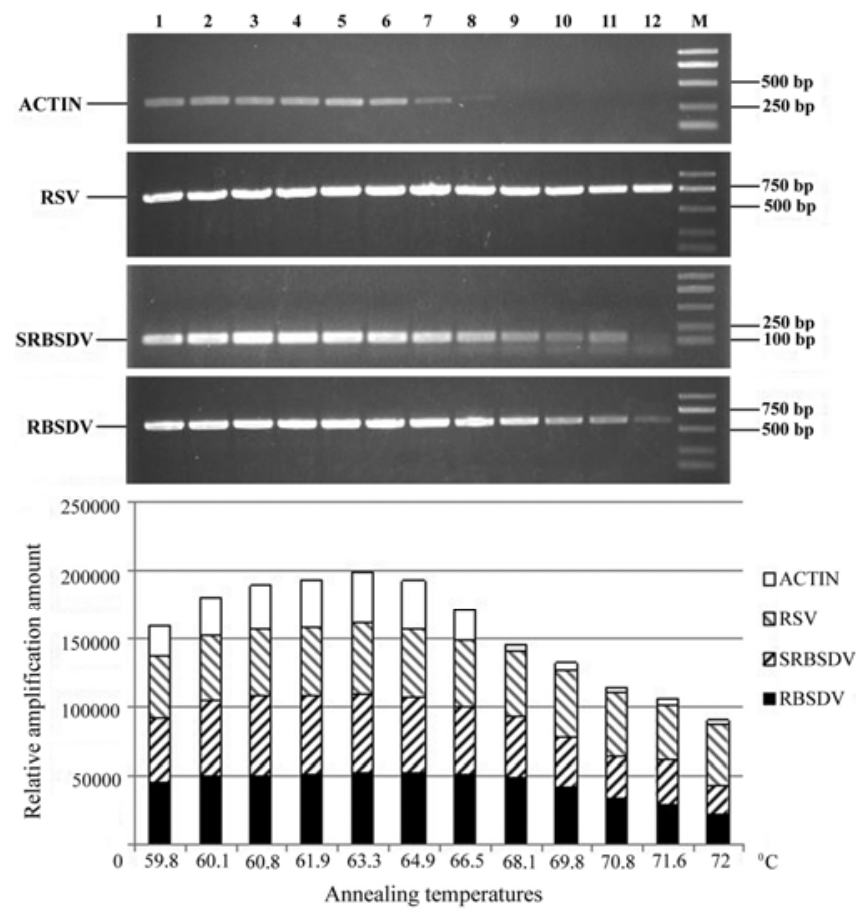

Fig. 1. Relative efficiency of reverse-transcription polymerase chain reaction at the gradient annealing temperatures (approximately 59.8 to $72.0^{\circ} \mathrm{C}$ ). M: DNA Marker. $\mathrm{RSV}=$ Rice stripe virus, SRBSDV = Southern rice black-streaked dwarf virus, and RBSDV = Rice black-streaked dwarf virus

Table 1. Primers designed for detection of Rice stripe virus (RSV), Rice black-streaked dwarf virus (RBSDV), and Southern rice black-streaked dwarf virus (SRBSDV)

\begin{tabular}{|c|c|c|c|}
\hline Primer name & Sequence & Target & Size of target fragment (bp) \\
\hline DRS-1 & 5'-CACTCTAGCTGATTTGCAGAAGGCA-3' & RSV & 757 \\
\hline DRS-2 & 5'-GGTCTTCACTTTCCCATTGGTGATG-3' & & \\
\hline DRB-1 & 5'-ACTAAGCTTATTTGCTACСТCСАAAC- $3^{\prime}$ & RBSDV & 592 \\
\hline DRB-2 & 5'-ATTAGTRCGCAAMGTGGACAAACTG-3' (R=A,G; M=A,C) & $\ldots$ & $\ldots$ \\
\hline DRZ-1 & $5^{\prime}$-CGCTTTAGATGCTGACAAATCACTTTTA- $3^{\prime}$ & SRBSDV & 142 \\
\hline DRZ-2 & 5'-СТССТTTTCTAAGTGCAGACAGTCC-3' & $\ldots$ & $\ldots$ \\
\hline ACT-1 & 5'-CCYGAYGGYCARGTRATCACMATTGG-3' (Y=C,T; R=A,G; M=A,C) & Actin & 347 \\
\hline ACT-2 & 5'-GAKATCCACATCTGYTGGAARGTG-3' (K=G,T; Y=C,T; R=A,G) & $\ldots$ & $\ldots$ \\
\hline
\end{tabular}


standard samples or with mixtures of two or three of the samples (Fig. 2). No detectable fragments except those from the Actin gene were amplified with the primer mixture using samples of healthy rice plants or plants infected by Rice gall dwarf virus, Rice ragged stunt virus, Tobacco mosaic virus, or Potato virus $Y$ (data not shown). In addition, we purified some of the fragments and determined their nucleotide sequences. These sequences were always $>98 \%$ identical to the corresponding regions of the standard samples. Therefore, these results consistently indicated that the primer pairs were specific for the three viruses and that the multiple (m)RT-PCR method can be efficiently used to detect them simultaneously. There were no obvious differences in the RT-PCR optimization results between the four types of sample (rice, maize, SBPH, and WBPH).

To analyze the sensitivity of the method, we performed the RTPCR with the primer mixture and a dilution series of standard sample mixtures. Expected fragments were still clearly detectable when the sample mixture was diluted up to $1 / 10,000$, indicating that the mRT-PCR method was highly sensitive (Fig. 2, lanes 21 to 25$)$.

Survey in China. The method was routinely used during 2008 to 2011 to detect viruses in rice plant samples from Guangdong, Zhejiang, Hubei, and Hunan Provinces and Shanghai City, China There were also some maize plant samples collected from Shandong and Zhejiang Provinces and planthopper samples (SBPH and WBPH) from Zhejiang, Hainan, Hunan, Shanghai, and Shandong Provinces. Details of sample numbers and the viruses detected are given in Table 2 and some typical results of the assays are shown in Figure 3. SRBSDV was detectable in both rice and planthopper samples from Guangdong, Hainan, Shanghai, Hunan, Hubei, and Zhejiang Provinces, China, confirming that the disease had spread since its initial discovery in Guangdong and Hainan. The proportions of viruliferous WBPH from Hunan and Hainan Provinces were higher than those from Zhejiang Province and Shanghai City, apparently correlating with the incidence, severity, and damage of the disease (8). In maize and planthopper samples from 21 counties

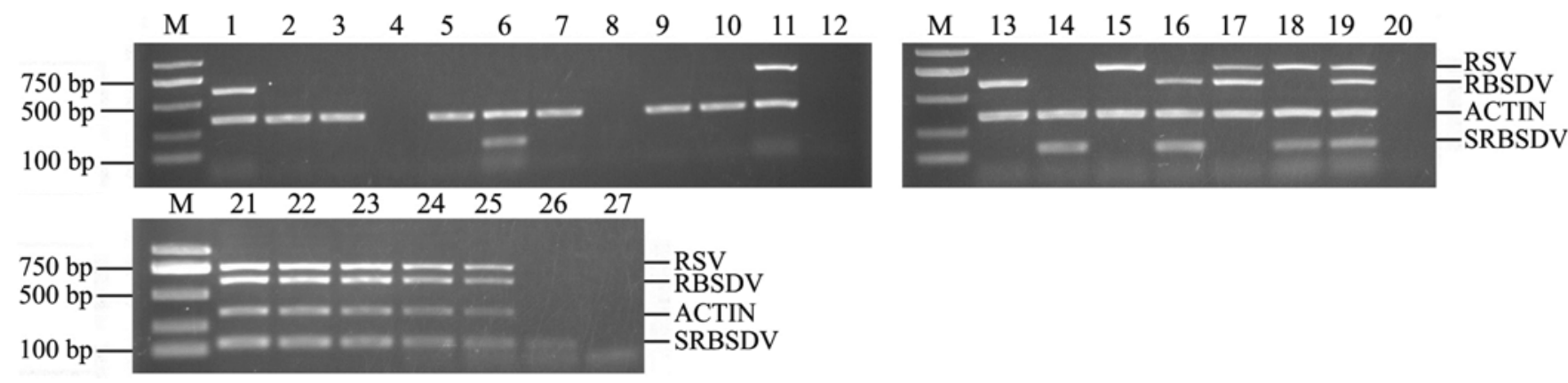

Fig. 2. Analysis of the specificity and sensitivity of the reverse-transcription polymerase chain reaction. M: DNA marker. Rice black-streaked dwarf virus (RBSDV) samples (lanes 1, 5, 9, and 13), Southern rice black-streaked dwarf virus (SRBSDV) samples (lanes 2, 6, 10, and 14), Rice stripe virus (RSV samples (lanes 3, 7, 11, and 15), and no template (lanes 4, 8, 12, and 20) were tested with primers DRB-1/DRB-2 (designed for RBSDV; lanes 1-4), DSR-1/DSR-2 (designed for SRBSDV; lanes 5-8), DRS-1/DRS-2 (designed for RSV; lanes 9-12), or a mixture of all three primer pairs (lanes 13-15). Lanes 16-19 show results from using a mixture of all three primer pairs on mixed plant samples (RBSDV+SRBSDV, RSV+RBSDV, RSV+SRBSDV, and RSV+RBSDV+SRBSDV, respectively). Lanes 21-27 show results from using a dilution series (steps of 1:10) of mixed plant samples with a mixture of all three primer pairs.

Table 2. Results of tests on samples of rice, maize, small brown planthopper (SBPH), or white-backed planthopper (WBPH) from Vietnam or various provinces in China collected in 2008 to $2011^{\mathrm{a}}$

\begin{tabular}{|c|c|c|c|c|c|c|c|c|}
\hline \multirow[b]{2}{*}{ Location } & \multicolumn{4}{|c|}{ Numbers of samples tested } & \multicolumn{4}{|c|}{ Numbers of samples in which viruses were detected } \\
\hline & Rice & Maize & SBPH & WBPH & RBSDV & SRBSDV & RSV & RBSDV/RSV \\
\hline Shanghai & 30 & $\ldots$ & $\ldots$ & $\ldots$ & $\ldots$ & 21 & $\ldots$ & $\ldots$ \\
\hline Shanghai & $\ldots$ & $\ldots$ & $\ldots$ & 546 & $\ldots$ & 9 & $\ldots$ & $\ldots$ \\
\hline Hubei & 8 & $\ldots$ & $\ldots$ & $\ldots$ & $\ldots$ & 5 & $\ldots$ & $\ldots$ \\
\hline Hunan & 48 & $\ldots$ & $\ldots$ & $\ldots$ & $\ldots$ & 48 & $\ldots$ & $\ldots$ \\
\hline Hunan & $\ldots$ & $\ldots$ & $\ldots$ & 190 & $\ldots$ & 5 & $\cdots$ & $\cdots$ \\
\hline Hainan & $\cdots$ & $\begin{array}{l}\cdots \\
\cdots\end{array}$ & $\cdots$ & 190 & $\cdots$ & 6 & $\cdots$ & $\cdots$ \\
\hline Guangdong & 25 & $\ldots$ & $\ldots$ & $\ldots$ & $\ldots$ & 23 & $\ldots$ & $\ldots$ \\
\hline Shandong & $\ldots$ & 77 & $\ldots$ & $\ldots$ & 51 & $\ldots$ & $\ldots$ & $\ldots$ \\
\hline Shandong & & $\ldots$ & 208 & $\ldots$ & 9 & . & $\ldots$ & $\ldots$ \\
\hline Zhejiang & 1,944 & $\ldots$ & $\ldots$ & $\ldots$ & 627 & 697 & 471 & $\ldots$ \\
\hline Zhejiang & $\ldots$ & 22 & $\ldots$ & $\ldots$ & 20 & $\ldots$ & $\ldots$ & $\ldots$ \\
\hline Zhejiang & $\ldots$ & & 893 & $\ldots$ & 26 & 2 & 53 & 2 \\
\hline Zhejiang & $\ldots$ & $\ldots$ & $\ldots$ & 3,708 & 3 & 84 & $\ldots$ & $\ldots$ \\
\hline
\end{tabular}

a Abbreviations: Rice black-streaked dwarf virus (RBSDV), Southern rice black-streaked dwarf virus (SRBSDV), and Rice stripe virus (RSV).
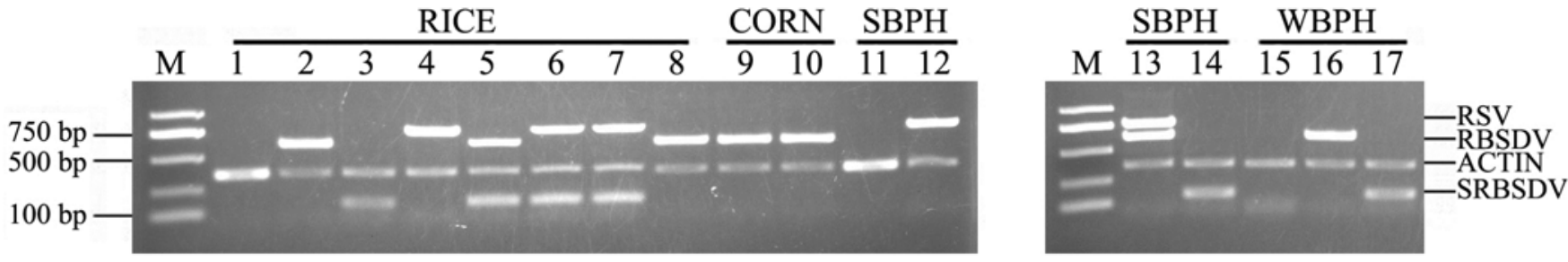

Fig. 3. Use of the multiplex reverse-transcription polymerase chain reaction method with different samples. M: DNA marker; lane 1: healthy rice plant sample; lanes 2-8: infected rice samples; lanes 9-10: infected maize samples; lane 11: virus-free small brown planthopper (SBPH) sample; lanes12-14: viruliferous SBPH samples; lane 15: virus-free white-back planthopper (WBPH) sample; lanes 16-17: viruliferous WBPH samples. 
in Shandong Province in northeastern China, only RBSDV was detectable (and at a rather high incidence), suggesting that maize rough dwarf disease in this province was still mainly caused by RBSDV. However, all three rice viruses were detectable in plant and planthopper samples from Zhejiang Province and two of the viruses were sometimes found in the same plant or planthopper sample (Fig. 3, lane 5 to 7 and 13). In particular, mixed infections of SRBSDV and RSV were detected in plant samples from a paddy field in Taizhou City, mixed infections of RBSDV and RSV were detected in plant samples from a paddy field in Lin' an County, and mixed infections of RBSDV and SRBSDV were detected in plant samples from paddy fields in Taizhou City and Lin'hai and Pujiang Counties. In addition, RBSDV was detectable in some WBPH samples and SRBSDV was detectable in some SBPH samples, although these are not the principal vectors of the respective viruses.

Detailed survey in Zhejiang Province, China. The method also enabled us to further investigate the distribution of the three

Table 3. Results of tests on samples of rice and maize collected from various counties of Zhejiang province in China in 2008 to $2011^{\mathrm{a}}$

\begin{tabular}{|c|c|c|c|c|c|c|c|c|}
\hline \multirow[b]{2}{*}{ Counties } & \multicolumn{2}{|c|}{ Number of samples tested } & \multicolumn{6}{|c|}{ Viruses detected } \\
\hline & Rice & Maize & RBSDV & SRBSDV & RSV & RBSDV/RSV & RBSDV/SRBSDV & SRBSDV/RSV \\
\hline Anji & $\ldots$ & 5 & 5 & $\ldots$ & $\ldots$ & $\ldots$ & $\ldots$ & $\ldots$ \\
\hline Anji & 32 & $\ldots$ & $\ldots$ & 4 & 19 & $\ldots$ & $\ldots$ & $\ldots$ \\
\hline Cangnan & 19 & $\ldots$ & 16 & $\ldots$ & $\ldots$ & $\ldots$ & $\ldots$ & $\ldots$ \\
\hline Changxing & 30 & $\ldots$ & $\ldots$ & $\ldots$ & 29 & $\ldots$ & $\ldots$ & $\ldots$ \\
\hline Cixi & 43 & $\ldots$ & 20 & $\ldots$ & 19 & $\ldots$ & $\ldots$ & $\ldots$ \\
\hline Cun'an & $\ldots$ & 3 & 3 & $\ldots$ & $\ldots$ & $\ldots$ & $\ldots$ & $\ldots$ \\
\hline Cun'an & 31 & $\ldots$ & $\ldots$ & 13 & 17 & $\ldots$ & $\ldots$ & $\ldots$ \\
\hline Deqing & 29 & $\ldots$ & $\ldots$ & $\ldots$ & 20 & $\ldots$ & $\ldots$ & $\ldots$ \\
\hline Dongyang & 11 & $\ldots$ & 10 & $\ldots$ & $\ldots$ & $\ldots$ & $\ldots$ & $\ldots$ \\
\hline Fenghua & 17 & $\ldots$ & 15 & $\ldots$ & $\ldots$ & $\ldots$ & $\ldots$ & $\ldots$ \\
\hline Fuyang & 28 & $\ldots$ & $\ldots$ & 14 & 13 & $\ldots$ & $\ldots$ & $\ldots$ \\
\hline Haining & 18 & $\ldots$ & $\ldots$ & $\ldots$ & 15 & $\ldots$ & $\ldots$ & $\ldots$ \\
\hline Haiyan & 19 & $\ldots$ & $\ldots$ & $\ldots$ & 19 & $\ldots$ & $\ldots$ & $\ldots$ \\
\hline Hangzhou & 59 & $\ldots$ & 20 & 16 & 7 & $\ldots$ & $\ldots$ & $\ldots$ \\
\hline Huzhou & 37 & $\ldots$ & $\ldots$ & 15 & 20 & $\ldots$ & $\ldots$ & $\ldots$ \\
\hline Jiande & 14 & $\ldots$ & $\ldots$ & $\ldots$ & 12 & $\ldots$ & $\ldots$ & $\ldots$ \\
\hline Jiangshan & 25 & $\ldots$ & 12 & 12 & $\ldots$ & $\ldots$ & $\ldots$ & $\ldots$ \\
\hline Jiashan & 27 & $\ldots$ & $\ldots$ & $\ldots$ & 23 & $\ldots$ & $\ldots$ & $\ldots$ \\
\hline Jiaxing & 22 & $\ldots$ & $\ldots$ & $\ldots$ & 22 & $\ldots$ & $\ldots$ & $\ldots$ \\
\hline Jingyun & 36 & $\ldots$ & 18 & 11 & $\ldots$ & $\ldots$ & $\ldots$ & $\ldots$ \\
\hline Jinhua & 62 & $\ldots$ & 15 & 45 & $\ldots$ & $\ldots$ & $\ldots$ & $\ldots$ \\
\hline Kaihua & 36 & $\ldots$ & 18 & 15 & $\ldots$ & $\ldots$ & $\ldots$ & $\ldots$ \\
\hline Lanxi & 20 & $\ldots$ & 20 & $\ldots$ & $\ldots$ & $\ldots$ & $\ldots$ & $\ldots$ \\
\hline Lin'an & 26 & $\ldots$ & 21 & 5 & 2 & 2 & $\ldots$ & $\ldots$ \\
\hline Lin'an & & 11 & 9 & $\ldots$ & $\ldots$ & $\ldots$ & $\ldots$ & $\ldots$ \\
\hline Linhai & 190 & $\ldots$ & 12 & 168 & 5 & $\ldots$ & 3 & $\ldots$ \\
\hline Lishui & 36 & $\ldots$ & 10 & 26 & $\ldots$ & $\ldots$ & $\ldots$ & $\ldots$ \\
\hline Longyou & 18 & $\ldots$ & 15 & $\ldots$ & $\ldots$ & $\ldots$ & $\ldots$ & $\ldots$ \\
\hline Ningbo & 19 & $\ldots$ & $\ldots$ & $\ldots$ & 17 & $\ldots$ & $\ldots$ & $\ldots$ \\
\hline Ninhai & 16 & $\ldots$ & $\ldots$ & $\ldots$ & 16 & $\ldots$ & $\ldots$ & $\ldots$ \\
\hline Pinghu & 28 & $\ldots$ & $\ldots$ & $\ldots$ & 27 & $\ldots$ & $\ldots$ & $\ldots$ \\
\hline Pujiang & 69 & $\ldots$ & 11 & 56 & $\ldots$ & $\ldots$ & 1 & $\ldots$ \\
\hline Qingtian & 40 & $\ldots$ & 15 & $\ldots$ & 19 & $\ldots$ & $\ldots$ & $\ldots$ \\
\hline Qingyuan & 28 & $\ldots$ & 21 & $\ldots$ & $\ldots$ & $\ldots$ & $\ldots$ & $\ldots$ \\
\hline Quzhou & 32 & $\ldots$ & 21 & 8 & $\ldots$ & $\ldots$ & $\ldots$ & $\ldots$ \\
\hline Rui'an & 18 & $\ldots$ & 16 & $\ldots$ & $\ldots$ & $\ldots$ & $\ldots$ & $\ldots$ \\
\hline Shangyu & 47 & $\ldots$ & 21 & $\ldots$ & 20 & $\ldots$ & $\ldots$ & $\ldots$ \\
\hline Shanmen & 29 & $\ldots$ & 26 & $\ldots$ & $\ldots$ & $\ldots$ & $\ldots$ & $\ldots$ \\
\hline Shaoxing & 64 & $\ldots$ & 17 & 23 & 20 & $\ldots$ & $\ldots$ & $\ldots$ \\
\hline Shaoxingxian & 17 & $\ldots$ & $\ldots$ & $\ldots$ & 17 & $\ldots$ & $\ldots$ & $\ldots$ \\
\hline Shengzhou & 9 & $\ldots$ & 8 & $\ldots$ & $\ldots$ & $\ldots$ & $\ldots$ & $\ldots$ \\
\hline Suichang & 31 & $\ldots$ & $\ldots$ & 30 & $\ldots$ & $\ldots$ & $\ldots$ & $\ldots$ \\
\hline Taishun & 45 & $\ldots$ & 27 & 15 & $\ldots$ & $\ldots$ & $\ldots$ & $\ldots$ \\
\hline Taizhou & 63 & $\ldots$ & 25 & 22 & 17 & $\ldots$ & 1 & 1 \\
\hline Tiantai & 31 & $\ldots$ & 5 & 7 & 10 & $\ldots$ & $\ldots$ & $\ldots$ \\
\hline Tonglu & 59 & $\ldots$ & 23 & 25 & 9 & $\ldots$ & $\ldots$ & $\ldots$ \\
\hline Tongxiang & 26 & $\ldots$ & $\ldots$ & $\ldots$ & 23 & $\ldots$ & $\ldots$ & $\ldots$ \\
\hline Wencheng & 8 & $\ldots$ & 6 & $\ldots$ & $\ldots$ & $\ldots$ & $\ldots$ & $\ldots$ \\
\hline Wenling & $\ldots$ & 3 & 3 & $\ldots$ & $\ldots$ & $\ldots$ & $\ldots$ & $\ldots$ \\
\hline Wenling & 38 & $\ldots$ & $\ldots$ & 26 & 9 & $\ldots$ & $\ldots$ & $\ldots$ \\
\hline Wenzhou & 33 & $\ldots$ & 15 & 17 & $\ldots$ & $\ldots$ & $\ldots$ & $\ldots$ \\
\hline Wuyi & 23 & $\ldots$ & $\ldots$ & 20 & $\ldots$ & $\ldots$ & $\ldots$ & $\ldots$ \\
\hline Xianju & 30 & $\ldots$ & 30 & $\ldots$ & $\ldots$ & $\ldots$ & $\ldots$ & $\ldots$ \\
\hline Xinchang & 11 & $\ldots$ & 9 & $\ldots$ & $\ldots$ & $\ldots$ & $\ldots$ & $\ldots$ \\
\hline Yiwu & 30 & $\ldots$ & 28 & $\ldots$ & $\ldots$ & $\ldots$ & $\ldots$ & $\ldots$ \\
\hline Yongjia & 24 & $\ldots$ & 19 & $\ldots$ & $\ldots$ & $\ldots$ & $\ldots$ & $\ldots$ \\
\hline Yongkang & 29 & $\ldots$ & $\ldots$ & 27 & $\ldots$ & $\ldots$ & $\ldots$ & $\ldots$ \\
\hline Yueqing & 48 & $\ldots$ & 19 & 26 & $\ldots$ & $\ldots$ & $\ldots$ & $\ldots$ \\
\hline Yuhuan & 39 & $\ldots$ & 10 & 28 & $\ldots$ & $\ldots$ & $\ldots$ & $\ldots$ \\
\hline Yuyao & 24 & $\ldots$ & 12 & $\ldots$ & 11 & $\ldots$ & $\ldots$ & $\ldots$ \\
\hline Zhuji & 51 & $\ldots$ & 21 & 13 & 14 & $\ldots$ & $\ldots$ & $\ldots$ \\
\hline
\end{tabular}

a Abbreviations: Rice black-streaked dwarf virus (RBSDV), Southern rice black-streaked dwarf virus (SRBSDV), and Rice stripe virus (RSV). 
viruses in plant and planthopper samples from 57 of the 70 counties or cities throughout Zhejiang Province during 2008 to 2011. Results are provided in Table 3 and the general distribution of the three viruses is shown in Figure 4. Most plant samples contained only a single virus and none contained all three. RSV was mostly found in the northern half of the province and its distribution did not appear to be correlated (either positively or negatively) with that of RBSDV, even though both viruses are transmitted by the same vector. RBSDV was detected in 39 counties or cities and, thus, was very widely distributed throughout the province (except the far northeast), although the disease was not as serious in recent years as at the end of the 20th century. All the maize samples tested from four counties or cities had only RBSDV, confirming that the virus has reemerged and become prevalent recently in these principal maize-growing areas of Zhejiang Province. SRBSDV was also widely distributed throughout the province (except the far northeast). In three adjacent counties (Yongkang, Suichang, and Wuyi), where the disease was first reported in the province, only SRBSDV was detected. All three viruses were detected in 10 counties or cities but it was apparent that SRBSDV has become the predominant viral pathogen in Linhai County in recent years.

\section{Discussion}

The RT-PCR-based assay remains one of best options for the early detection and accurate diagnosis of plant RNA viruses due to its rapidity, sensitivity, and reproducibility. Here, we developed an mRT-PCR method for detection of RSV, RBSDV, and SRBSDV in view of the current epidemiological situation of viral diseases on rice plants in Eastern China. This is also the first report on simultaneous detection of these three major rice viruses. Our protocol was designed from a large number of sequences to detect all isolates of RSV, RBSDV, and SRBSDV. The sizes of the amplification products are specific for each virus and easy to distinguish from one another. The method has been successfully used to detect viruses in rice and maize plant samples and in single SBPH and WBPH vector insects.

In Zhejiang Province, Eastern China, RBSDV and RSV had been detected in most of the counties or cities surveyed during 2003 to 2007 by Wang et al. $(10,11)$ but our results show that both viruses had continued to spread and were now present in a further 12 (RBSDV) or 5 (RSV) counties or cities, indicating that control measures are still required to stop the spread of diseases and minimize yield losses. SRBSDV was detected in 27 counties or cities,

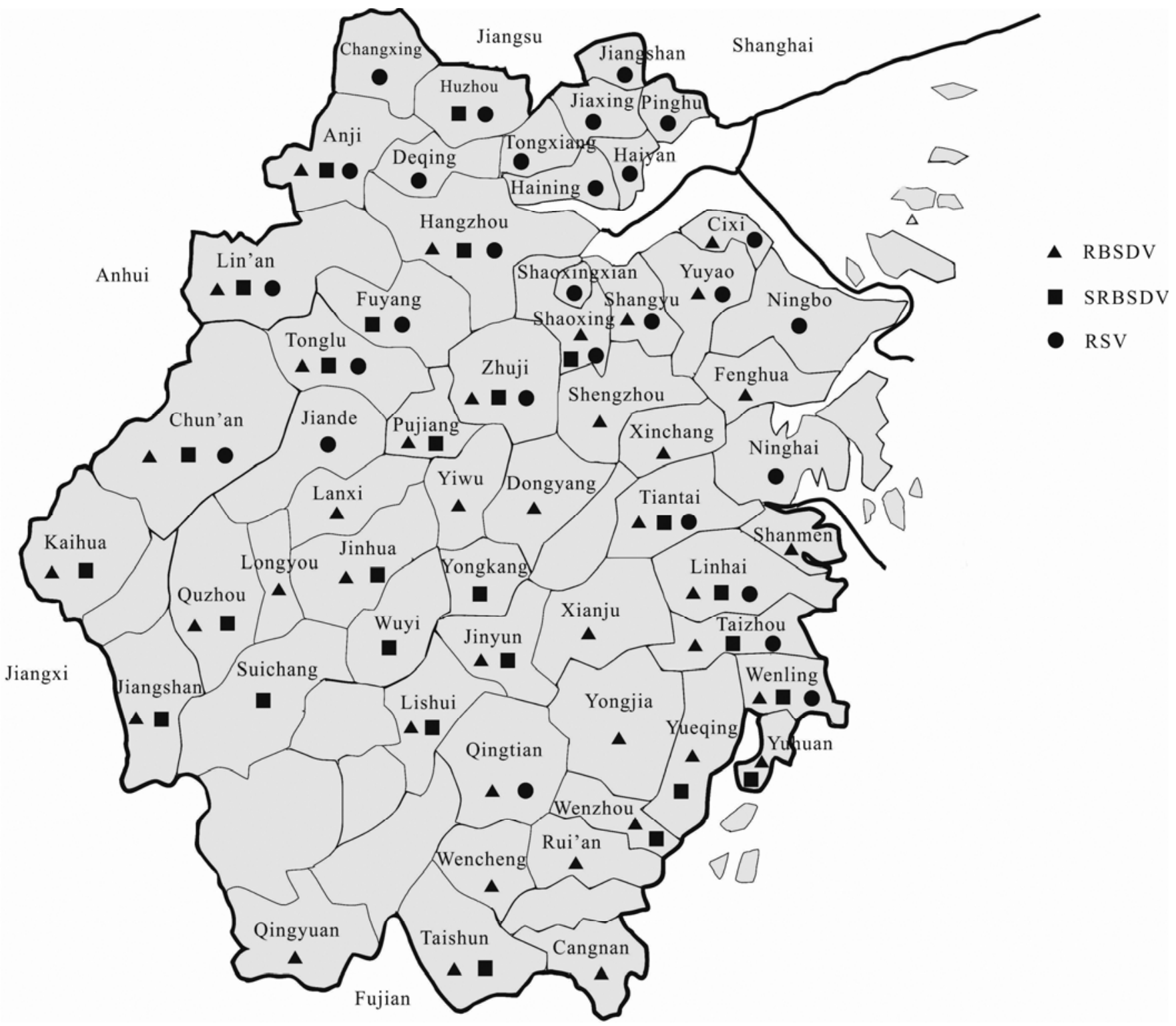

Fig. 4. Distribution of Rice black-streaked dwarf virus (RBSDV), Southern rice black-streaked dwarf virus (SRBSDV), and Rice stripe virus (RSV) in samples from Zhejiang Province, Eastern China during 2008 to 2011. Sample numbers and frequency of detection are provided in Table 3. 
showing that this newly emerging disease had also spread substantially. More effort is needed to monitor and control the threat from this novel viral disease. Individual plants infected by two of the viruses were occasionally found but the vast majority of plants contained only a single virus, although two or all three viruses were often present in the county and even within the same field. RBSDV and SRBSDV were both detected in individual planthoppers of the both species, strongly suggesting that these planthoppers can acquire either virus. However, it remains unclear whether SBPH can transmit SRBSDV or whether WBPH can transmit RBSDV. RSV and RBSDV are both transmitted by SBPH and two insect samples contained both viruses, although experimental evidence of joint transmission has not been reported. The samples from some counties in Zhejiang Province appeared to have RSV alone while those from other counties had only RBSDV; however, there were also counties where both viruses were present. Although WBPH is a migratory insect, SBPH usually only moves for relatively short distances (10) and it is likely that these patterns of RSV and RBSDV infection reflect differences in local overwintering sources of inoculum that change relatively slowly over time. In the SBPH samples from Zhejiang Province, the proportion carrying RSV was about twice that of RBSDV, which may be related to the ability of SBPH to transmit RSV through the eggs $(1,9)$.

In conclusion, it has been proven that the method is useful for accurate diagnosis, large-scale surveys, and mapping the complex patterns of overlapping distribution and multiple infections. There have been few studies of the epidemiology of these viruses and this sensitive technique will be useful for investigating a series of unsolved biological problems that should contribute to their forecasting, monitoring, and control.

\section{Acknowledgments}

This work was funded by National Science and Technology Support Program (2012BAD19B03), the China 863 and 973 program (2007AA10Z414 and 2010CB126203), the International Science and Technology Cooperation Project (2007DFB30350), the Special Fund for Agro-scientific Research in the Public Interest of China (201003031), the Zhejiang Provincial Science and Technology Project (2010C12027), and the Zhejiang Provincial Foundation for Natural Science (Z305165 and Y3090657). We thank M. Adams, Rothamsted Research, UK for help correcting the English of the manuscript.

\section{Literature Cited}

1. Falk, B. W., and Tsai, J. H. 1998. Biology and molecular biology of viruses in the genus Tenuivirus. Annu. Rev. Phytopathol. 36:139-163.

2. Isogai, M., Uyeda. I., and Lee. B.-C. 1998. Detection and assignment of proteins encoded by rice black streaked dwarf fijivirus S7, S8, S9, and S10. J. Gen. Virol. 79:1487-1494.

3. Ji, Y. H., Gao, R. Z., Zhang. Y., Chen, Z. B., Zhou, T., Fan, Y. J., and Zhou, Y. J. 2011. A simplified method for quick detection of rice black-streaked dwarf virus and southern rice black-streaked dwarf virus. Chin. J. Rice Sci. 25:91-94. (In Chinese)

4. Larkin, M. A., Blackshields, G.., Brown, N. P., Chenna, R., McGettigan, P.
A., McWilliam, H., Valentin, F., Wallace, I. M., Wilm, A., Lopez, R. Thompson, J. D., Gibson, T. J., and Higgins, D. G. 2007. Clustal W and Clustal X version 2.0. Bioinformatics. 23:2947-2948.

5. Le, D. T., Netsua, O., Uehara-Ichiki, T., Shimizua, T., Choi, I. R., Omura, T., and Sasaya, T. 2010. Molecular detection of nine rice viruses by a reverse-transcription loop-mediated isothermal amplification assay. J. Virol. Methods 170:90-93.

6. Liang, D., Qu, Z., Ma, X., and Hull, R. 2005. Detection and localization of Rice stripe virus gene products in vivo. Virus Genes 31:211-221.

7. Shen, J. H., Shang, J. M., and Liu, G. J. 2003. Management of the whitebacked planthopper, Sogatella furcifera in China. Chin. J. Rice Sci. 17 (Suppl.):7-22. (In Chinese)

8. Ta, H. A., Zhang, H. M., Yang, J., Chen, J. P., Hébrard, E., Zhou, G. H., Vien, N. V., and Cheng, J. A. 2011. Identification, characterization and distribution of Southern rice black-streaked dwarf virus in Vietnam. Plant Dis. 95:1063-1069.

9. Toriyama, S. 2000. Rice stripe virus. Descriptions of Plant Viruses, No. 375. Association of Applied Biologists, Wellesbourne, UK. http://www. dpvweb.net/dpv/showdpv.php?dpvno=375

10. Wang, H. D., Chen, J. P., Wang, A. G., Jiang, X. H., and Adams, M. J. 2009. Studies on the epidemiology and yield losses from rice black-streaked dwarf disease in a recent epidemic in Zhejiang Province, China. Plant Pathol. 58:815-825.

11. Wang, H. D., Chen, J. P., Zhang, H. M., Sun, X. L., Zhu, J. L., Wang, A.G., Sheng, W. X., and Adams, M. J. 2008. Recent Rice stripe virus epidemics in Zhejiang Province, China, and experiments on sowing date, disease-yield loss relationships, and seedling susceptibility. Plant Dis. 92:1190-1196.

12. Wang, Q., Yang, J., Zhou, G. H., Zhang, H. M., Chen, J. P., and Adams, M. J. 2010. The complete genome sequence of two isolates of a new rice-infecting fijivirus from China. J. Phytopathol. 158:733-737.

13. Zhang, H. M., Chen, J. P., Lei, J. L., and Adams, M. J. 2001. Sequence analysis shows that a dwarfing disease on rice, wheat and maize in China is caused by Rice black-streaked dwarf virus. Eur. J. Plant Pathol. 107:563567.

14. Zhang, H. M., Sun, H. R., Wang, H. D., and Chen, J. P. 2007. Advances in the studies of molecular biology of Rice stripe virus. Acta Phytophylacica Sin. 34:436-450. (In Chinese).

15. Zhang, H. M., Yang, J., Chen, J. P., and Adams, M. J. 2008. A blackstreaked dwarf disease on rice in China is caused by a novel fijivirus. Arch. Virol. 153:1893-1898.

16. Zhang, H. M., Yang, J., Sun, H. R., Xin, X., Wang, H.D., Chen, J. P., and Adams, M. J. 2007. Genomic analysis of rice stripe virus Zhejiang isolate shows the presence of an OTU-like domain in the RNA1 protein and a novel sequence motif conserved within the intergenic regions of ambisense segments of tenuiviruses. Arch. Virol. 152:1917-1923.

17. Zhou, G. H., Wen, J. J., Cai, D. J., Li, P., Xu, D. L., and Zhang, S. G.. 2008 Southern rice black-streaked dwarf virus: A new proposed Fijivirus species in the family Reoviridae. Chin. Sci. Bull. 53:3677-3685.

18. Zhou, G. H., Xu, D. L., and Li, H. P. 2004. Identification of rice blackstreaked dwarf virus infecting rice in Guangdong. Pages 210-212 in: Proc Conf. Chin. Plant Pathol. Y. L. Peng, ed. China Agricultural Scientech Press, Beijing. (In Chinese)

19. Zhou, G. H., Zhang, S. G., Zou, S. F., Xu, Z. W., and Zhou, Z. Q. 2010 Occurrence and damage analysis of a new dwarf disease caused by Southern rice black-streaked dwarf disease. Plant Prot. 36:144-146. (In Chinese)

20. Zhou, Q., Zhu, J. Z., Liang, J. G., Chen, X. Y., and Gao, B. D. 2010. Rapid detection of Southern rice black-streaked dwarf virus. Genomics Appl. Biol. 29:1009-1012. (In Chinese) 